Alaska Division of Geological \& Geophysical Surveys

MISCELLANEOUS PUBLICATION 148

\title{
PACIFIC NORTHWEST EARTHQUAKES AND POTENTIAL EFFECTS ON ALASKA
}

\author{
ALASKA SEISMIC HAZARDS SAFETY COMMISSION, 2012 \\ Contributions by: \\ R.D. Koehler, G.A. Carver, R. Scher, L.W. Kelly, G. White, D. Miller, and J. Aho
}

August 2012

Released by

STATE OF ALASKA

DEPARTMENT OF NATURAL RESOURCES

Division of Geological \& Geophysical Surveys

3354 College Rd.

Fairbanks, Alaska 99709-3707

ASHSC Alaska Seismic Hazards 



\title{
PACIFIC NORTHWEST EARTHQUAKES AND POTENTIAL EFFECTS ON ALASKA
}

\author{
by
}

\section{ALASKA SEISMIC HAZARDS SAFETY COMMISSION, 2012}

\section{Executive Summary}

Although Alaska has significant economic ties with the Pacific Northwest (PNW), the relative impacts of a destructive PNW earthquake on Alaska's economy has not yet been evaluated. The importance of this issue lies in the quantity of imports and exports that are vital to Alaska's economy and pass through the seaports and transportation infrastructure in the PNW. Potential damaging earthquakes are likely to occur along the Cascadia subduction zone and/or upper crustal faults in Puget Sound. These earthquakes will be of the size and type that caused widespread damage and economic hardship along the coast of Japan in 2011 (great subduction earthquake) and in the city of Kobe, Japan, in 2005 (large upper crustal fault earthquake). The geologic effects of PNW earthquakes on infrastructure in the PNW region have been well described in numerous scenario reports; however, these reports do not detail the far-field secondary effects, such as potential impacts on Alaska's supply lines to and from the Lower 48 and the impact on Alaska's economy. This paper provides background on PNW earthquake potential, expected damage to that region, and its potential effects on Alaska; it serves as a basis for the Alaska Seismic Hazards Safety Commission's recommendation to the Alaska Legislature and Governor's Office in 2011 for state agencies to investigate potential impacts and develop contingency plans for such an event.

\section{Introduction}

Alaska is the most seismically active state in the United States, accounting for more earthquakes than the other 49 states combined. As a result, many regions in the state are exposed to significant seismic hazards from local earthquakes. However, not all of Alaska's seismic vulnerability is the result of earthquakes originating in the state. Because of Alaska's close economic and geographic ties with the Pacific Northwest, a great earthquake on the Cascadia subduction zone and/or large, shallow earthquakes on crustal faults in Washington state's Puget Sound region (fig. 1) are expected to have significant economic and societal impacts in Alaska.

The Pacific Northwest (PNW) region, particularly Puget Sound, is the gateway to Alaska and provides transportation, commercial facilities, and services vital for Alaska's imports, exports, and tourism industries. The majority of the processed food, refined fuel, and manufactured goods consumed and used in Alaska are imported through transportation terminals in the Puget Sound area. A significant part of Alaska's natural resource exports (including oil), the underpinnings of the state's economy, pass through Pacific Northwest ports, transportation centers, and refineries. Many boats in the commercial fishing fleet that deliver ocean-caught seafood to Alaska seafood processors are based out of Washington and Oregon. Many tourists who visit the state depart from and return to airports and cruise ship terminals located in the Pacific Northwest. Long-term restoration of Alaska's supply lines from and export pathways to the Lower 48 may take many months, even years, while damaged or destroyed infrastructure in the PNW is repaired or replaced.

The geologic aspects, engineering effects, and societal impact of subduction zone and Puget Sound crustal fault earthquakes on Pacific Northwest communities have been detailed in several recent scenario studies ${ }^{1,2,3,4}$. However, the impacts to Alaska's economy remain unstudied. Thus, given the substantial and crucial ties between Alaska and the Pacific Northwest, this paper considers the effects of potential PNW earthquakes, and evaluates potential impacts of and vulnerabilities to such seismic events on Alaska and its citizens. It is in the best interest of the State of Alaska to develop plans and mitigation strategies to minimize such impacts on Alaska before a damaging PNW earthquake compromises the state's principal economic lifelines. 


\section{Background}

The PNW coast between northern California and southern British Columbia lies along the Cascadia subduction zone, a system of major faults between the Gorda-Juan de Fuca and North American plates (fig. 1A). Research conducted over the last several decades has produced compelling evidence that the subduction zone is highly active and periodically generates great subduction earthquakes ${ }^{5,6}$ and accompanying tsunamis similar to the 2011 Tōhoku earthquake in Japan or the 1964 Good Friday earthquake in Alaska. The Cascadia subduction zone has a long history of generating magnitude $\sim 9$ earthquakes ${ }^{7}$ including a well-dated event on January $27,1700^{8,9}$. The 312 years that have elapsed since the 1700 event is longer than some of the intervals between previous Cascadia earthquakes. Thus, based on the past performance of the subduction zone, the next great Pacific Northwest earthquake could occur at any time.

In addition to the Cascadia subduction zone, recent research has identified clear evidence of multiple past earthquakes in the recent geologic past along a number of shallow crustal faults in the Puget Sound region $^{10,11}$ (fig. 1B). These faults are active and capable of generating future powerful earthquakes that would be highly destructive to the Puget Sound area. In some cases, the time since the last major earthquake is close to the average recurrence rate, suggesting that the next earthquake could occur at any time. Several of these faults are located close to Seattle and Tacoma and others underlie the central and northern Puget Sound area in close proximity to refineries that process much of Alaska's oil.
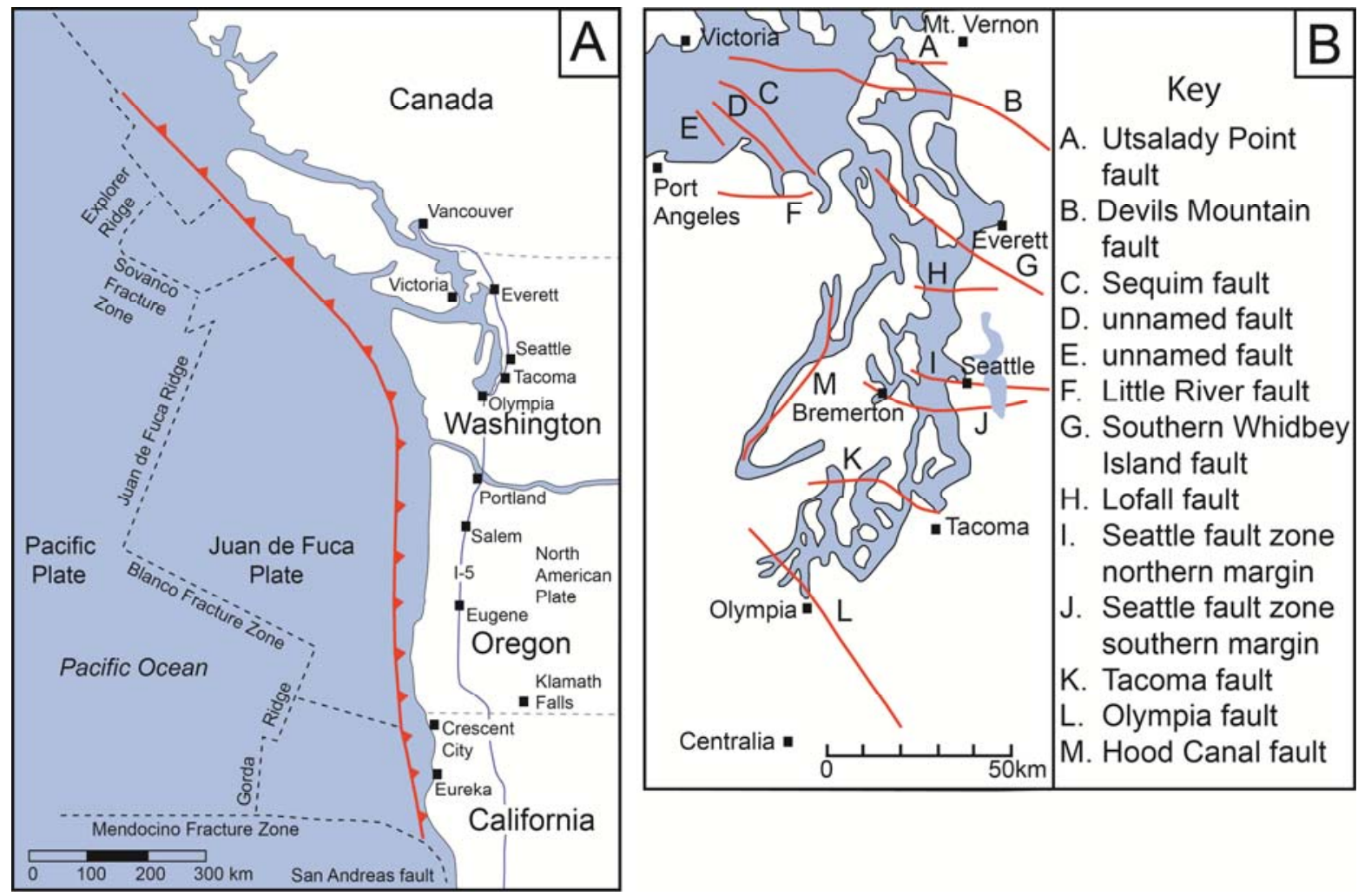

Figure 1. (A) The Cascadia Subduction Zone, stretching 900 miles ( 1,450 km) along the subduction boundary between the Juan de Fuca and North American plates offshore of the Pacific Northwest, is capable of generating great (M 9+) earthquakes. Illustration modified from CREW, 2005. (B) Active crustal faults in the Puget Sound region are capable of generating magnitude 6-7+ earthquakes. Importantly, the Seattle, Tacoma, Devils Mountain, and Utsalady faults pose significant hazards to population centers, seaports, industrial and commercial facilities critical to Alaska, and to refineries that process much of Alaska's North Slope oil. 
A great Cascadia earthquake or a shallow Puget Sound earthquake has the potential to disrupt transportation and commerce between Alaska and the Lower 48 for an extended period of time. This disruption would be especially acute in the days and weeks following the earthquake when the emphasis will focus on rescue and relief efforts in areas directly affected. Especially significant in the immediate aftermath of a destructive Cascadia or Puget Sound earthquake is the potential impact on receipt in Alaska of necessary products and supplies such as food and fuel. Temporary replacement of transportation, communication, and other vital links with the Lower 48 in the near term following the earthquake will incur significant costs and cause greatly reduced efficiency, particularly if no prior planning is in place.

\section{Effects of a major Pacific Northwest earthquake}

A major earthquake of concern to Alaska is likely to occur along either or both known earthquake source zones in the PNW including:

1. A great earthquake (Magnitude 8-9) on the Cascadia subduction zone. This event would produce substantial damage in a broad region along the entire coastal region from northern Vancouver Island to northern California.

2. A large earthquake (Magnitude 7-7.5) on an upper crustal fault within Puget Sound. The direct effects of this event would be localized to the Puget Sound region.

A magnitude 9 subduction zone earthquake along the Cascadia coast, similar to the 2011 earthquake in Japan, would cause unprecedented damage over a wide region from northern California to southern Canada and generate a large tsunami that would cause catastrophic damage to low-lying coastal facilities along the entire PNW coast ${ }^{1,2,3,4}$. Geologic evidence clearly supports the occurrence of multiple large earthquakes in the geologic record ${ }^{6}$ with recurrence intervals ranging between several hundred years to about a millenium ${ }^{7}$. Expected geologic effects from such an event will include strong, long-duration ground shaking lasting for several minutes, numerous landslides, widespread liquefaction, lateral spreads, ground failure, and tsunamis. Effects on the built environment will include fires, hazardous materials spills, power outages, disruption of transportation corridors, and damage or collapse of houses, large buildings, warehouses, and bridges. The destruction of roads, airport and port facilities, and rail lines will not only impact rescue and relief efforts but also disrupt commerce for weeks to many months. Some commercial activities will be permanently eliminated and many PNW businesses will never fully recover.

Along the coast, communities will be isolated from inland regions and each other due to damage to transportation routes by landslides, flooding in subsided low-lying areas, and collapse of bridges. Highway 101, the principal coastal highway, will be blocked in many places and not restored to full service for many weeks or months. Extensive damage is expected in low-lying coastal harbors and communities such as Long Beach and Ocean Shores in Washington, Seaside, Cannon Beach, Oceanside, Newport, Lincoln City, Florence, and North Bend-Coos Bay in Oregon, and Crescent City in California. Shoreline port facilities in Seattle, Tacoma, and the lower reaches of the Columbia River upstream as far as Portland also are highly vulnerable to a Cascadia tsunami. A magnitude 9 subduction earthquake would cause permanent land-level subsidence and result in tidal inundation of low-lying areas that were formerly above high tide along much of the coastline.

Inland U.S. Interstate 5, the main north-south highway linking the major PNW cities, will undergo bridge failures, landslides, and other earthquake-induced damage requiring weeks to months to repair. The major commercial cities of Seattle, Tacoma, Portland, and Vancouver (British Columbia) will undergo longterm power outages and disruptions of water, sewer, and natural gas service. Tall buildings, particularly vulnerable to long-period seismic shaking, and many poorly or unreinforced masonry buildings, will be extensively damaged. Soil conditions in many Puget Sound communities are susceptible to liquefaction and lateral spreads, the processes of saturated, loose, sandy soil liquefying during strong seismic shaking. 
Artificially filled ground in the Duwamish River Valley at the southern end of Elliott Bay in Seattle, location of many of the city's port facilities, is particularly susceptible to liquefaction, as are many of the margins of rivers, lakes, and Puget Sound shorelines. Ground failure processes will affect many port facilities, roads, petroleum terminals, airports, manufacturing plants, and warehouses essential to the processing and export of goods and services to Alaska (fig. 2).

An earthquake along one of the many upper crustal faults in Puget Sound would have similar effects as a Cascadia event, although less severe and less widespread ${ }^{3}$. Damage will be focused near the epicenter of the earthquake and along the particular fault that ruptured. Local tsunami waves may inundate low-lying areas and strong ground shaking, surface fault rupture, and other secondary effects are likely to cause local destruction severe enough to disrupt transportation and commerce infrastructure. Recent moderately sized earthquakes have caused economic devastation to modern cities (such as Kobe, Japan, 1995) and underscore the importance of planning for their occurrence, specifically the interruption of the supply of goods and services to Alaska.
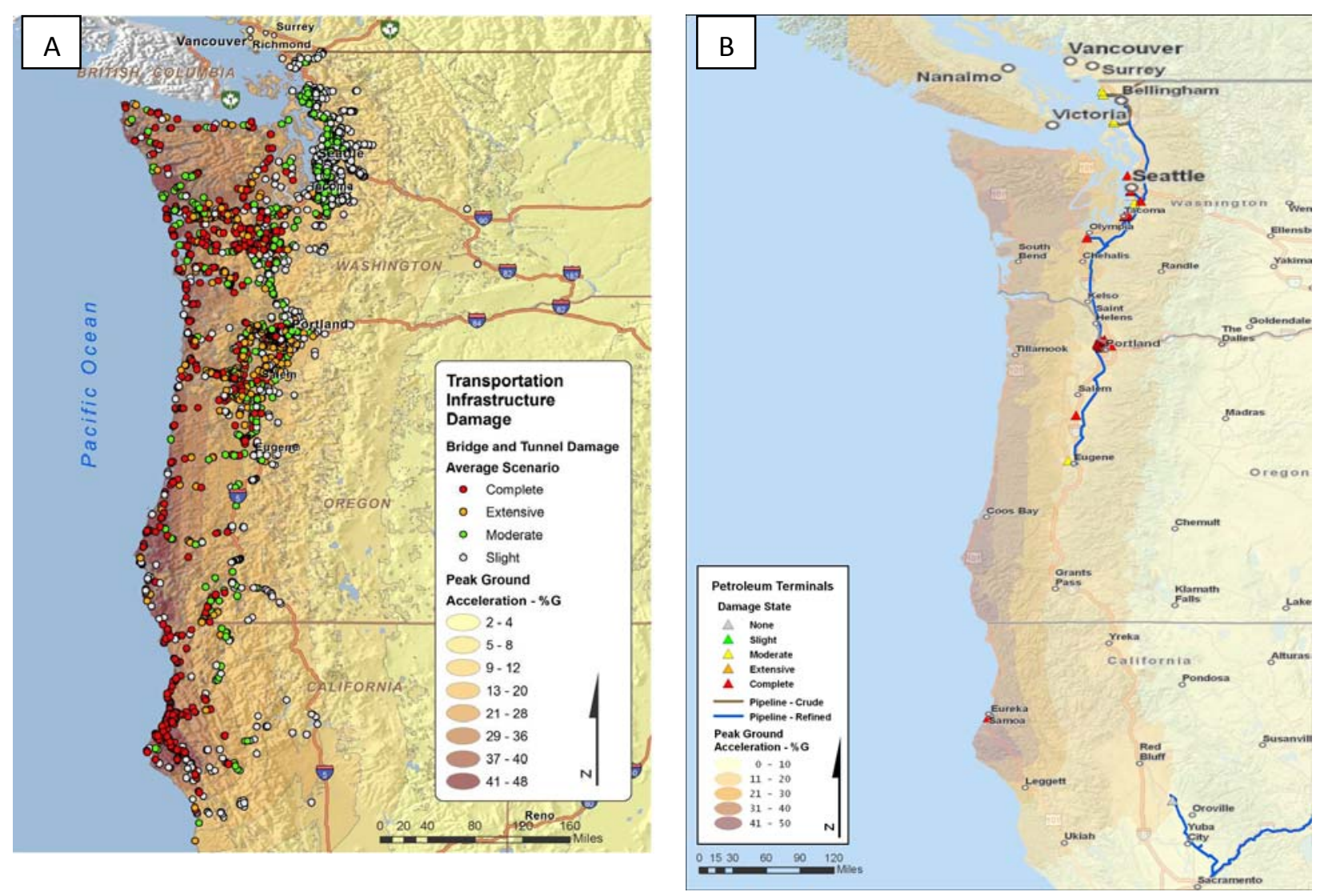

Figure 2. Potential damage estimated by HAZUS for a scenario Cascadia subduction zone earthquake. (A) Transportation infrastructure and (B) Petroleum terminals. Graphics provided by the U.S. Department of Homeland Security ${ }^{4}$. 


\section{Potential impacts to Alaska's economy related to a Pacific Northwest earthquake}

Major economic sectors that control Alaska's economic health are freight and transportation, petroleum, mining, tourism, and seafood. According to the 2009 state economic report, the overall economy GDP (gross domestic product) in Alaska was $\$ 41.7$ billion $^{12}$. Of that amount, $\$ 6.1$ billion is attributed to tax and royalty payments from oil and gas, $\$ 2.9$ billion from the mining industry, $\$ 3.4$ billion in visitor spending associated with tourism, and $\$ 5$ billion from the ex-vessel and wholesale seafood markets. The same report describes $\$ 87.9$ million in timber exports, $\$ 31.9$ million in agriculture industry receipts, and $\$ 14.2$ billion in federal government spending (including military). The 2009 state economic report does not account for other economic and revenue-generating activities in the state, such as the 2011 construction spending forecast (without oil and gas) at $\$ 4.2$ billion $^{13}$, or other private industry including transportation, medical, and general commerce.

A considerable part of Alaska's economy relies on transportation through facilities in the PNW. Much of this trade is transported to shipping ports by trucking on Interstate 5 and by rail from sources to the south and east. Damage and long-term disruption of these ports and trade routes would impair Alaska's ability to conduct business throughout the PNW. The potential impacts to several sectors of Alaska's economy due to a large earthquake in the PNW are described below.

\section{Freight and transportation}

Washington is the primary freight link for Alaska to the Lower 48 (the contiguous United States), and PNW ports and harbors provide a critical and interdependent service to the residents of Alaska. Together, the Port of Seattle and the Port of Tacoma facilities represent the third largest container load center in the United States, and Washingtons ports handle 8 percent of all U.S. exports ${ }^{14}$. The Port of Tacoma handles more than 70 percent of waterborne commerce between Alaska and the Continental United States ${ }^{15}$. Loss or compromise of services at these port facilities is highly probable in the event of a great Cascadia subduction earthquake or a large local earthquake and would have severe and immediate economic consequences not only for the Cascadia Region, but also for Alaskans who are dependent on container and air freight originating in Washington.

In addition to the port facilities, transportation facilities including ferry terminals and the associated shore-side network of roads and bridges, airports, railways and warehouses will also be impacted by a large earthquake. Transportation and utility losses create reactions up and down supply chains and can impact factory production, retailers, fishing, tourism, banking and health care sectors. Based on lessons learned in Japan (Kobe and Sendai), full economic recovery would take several years and have a multibillion-dollar effect on the economy. Many large and small businesses that serve the needs of Alaskans would be inoperable and alternative sources would have to be found. Undoubtedly, these services would eventually be obtained elsewhere, but not without long interruptions and at higher cost. Past experience with earthquakes of the size and type expected in the PNW shows lost revenue during the recovery period often exceeds the cost of repairs and replacement of damaged infrastructure.

With Pacific Northwest ports out of commission, considerable strain would be put on other transportation modes for consumer goods and commodities required to keep the state functional. Vital commodities from the Lower 48 such as gasoline, diesel, aviation fuel, food, and construction materials would diminish in variety and quantity and increase in cost. Without Pacific Northwest ports available to load barges and container ships with these commodities, the state and its consumers would rely on trucking to bring these supplies north in smaller amounts and at higher cost.

\section{Oil}

Nearly 90 percent (currently 89 percent) of the State of Alaska's operating budget is derived from oil revenues ${ }^{16}$, hence the economic impacts on oil exports from Alaska resulting from a PNW earthquake are potentially significant. Oil exports and the supply chain to and from the West Coast are vital to the health 
of the state of Alaska and its citizens. Loss in oil production will likely cause financial distress for Alaska and its stakeholders.

Much of the tanker traffic carrying domestic product derived from North Slope crude is bound for destinations along the West Coast that may be damaged during a PNW earthquake, including facilities at March Point, Ferndale, Cherry Point, and Port Angeles in Puget Sound. For example, in December 2010, the average daily throughput at the Valdez, Alaska, terminal was 646,890 barrels of crude, and tanker traffic departing for ports in the Puget Sound region accounted for over half (11,832,599 barrels) of the 20,053,585 barrels offloaded ${ }^{17}$. Either type of PNW earthquake considered in this paper could prevent much of the product from offloading at its destination. Table 1 shows the refining capacity of Puget Sound refineries. Damage to one or all of these facilities and the resulting reduction in refining capabilities could rapidly result in storage and offloading bottlenecks in the supply chain. The total storage for North Slope crude at the Valdez terminal is about 9 million barrels ${ }^{18}$. Thus, at the December 2010 production rate, the storage facilities would be at maximum capacity after about 14 days. If refining facilities are not available in the aftermath of a PNW earthquake, a storage problem could result in a potential shutdown of the pipeline.

Clearly, a loss in storage or refining capability in the Puget Sound region will directly impact production of North Slope crude. Remaining processing infrastructure in operating condition could potentially be called upon to offset the lack of processing capability at damaged facilities. However, it is unlikely the surviving refining capacity will be able to process all of Alaska's crude oil exports. It will be imperative for the owners of North Slope crude to identify alternative storage and refining capabilities along the West Coast outside of the Puget Sound area to meet the demands of domestic use. The impacts to Alaska's economy of longer shipping distances and potential delivery reductions are unknown.

Table 1. Refining capacity of Puget Sound Refineries receiving Alaska crude ${ }^{19}$.

\begin{tabular}{|c|c|c|c|}
\hline Destination & Owner & Location & $\begin{array}{c}\text { Throughput } \\
\text { (Barrels Per Day) }\end{array}$ \\
\hline March Point & Tesoro, Shell & Anacortes, WA & 255,000 barrels \\
\hline Cherry Point & $\mathrm{BP}$ & Blaine, WA & 202,000 barrels \\
\hline Ferndale & Conoco Phillips & Ferndale, WA & 100,000 barrels \\
\hline
\end{tabular}

\section{Tourism}

Tourism is another major contributor to Alaska's economy. In 2010, cruise ship visitors numbered $1,026,600$ persons, including passengers exiting the state by air after ending their cruise ${ }^{20}$. The majority of those passengers began or ended their cruises at the Ports of Vancouver and Seattle. Approximately one in ten jobs statewide depends on the travel industry ${ }^{21}$. Although alternate ports and airports outside of the affected regions in the Pacific Northwest are available to compensate for some of the lost transportation facilities in the affected region, these will involve longer travel distances, and increased demands on the alternate seaports and airports. How much of the increased traffic these alternate facilities can handle is not known and may not be sufficient to compensate fully for the lost capacity in the affected area. While air traffic may be more easily rerouted through alternate airports, cruise ship traffic is more specific to the PNW. Clearly the tourism industry in Alaska would be significantly impacted.

\section{Fishing}

Seafood processing is handled mainly at sea and at ports such as Dutch Harbor, Kodiak, and Southeast Alaska coastal communities ${ }^{22}$. To ensure freshness and quality of this resource as it is transported to market, prompt handling at PNW seaports is essential. In the event of an earthquake, damaged PNW 
seaports may result in reduced seafood handling capacity, and require rapid transfer to alternative handling facilities in California and elsewhere in the Pacific Rim at greater cost.

Many of the boats that commercially fish Alaska's waters are based in the PNW. The occurrence of an earthquake that generates a tsunami when these boats are berthed at home ports may result in the loss of many boats. Any reduction in the PNW-based Alaska fishing fleet would seriously impact seafood processors in many coastal communities by reducing harvest and deliveries.

\section{Communications}

A major earthquake in the PNW may disrupt communications between the Lower 48 and Alaska, especially during the immediate aftermath of the event. Communication in the affected area of the PNW will be the most seriously affected and may be out of service or disrupted for extended periods. Rerouted service may be slower and capacity reduced. Thus, communication alternatives will need to be employed to communicate with the Lower 48, including ham radio, satellite phone, cellular systems, microwave, and sea-floor fiberoptic cables. The fiberoptic system between the Lower 48 and Alaska includes cables on the ocean floor that are susceptible to breakage from submarine slope failures along the continental shelf. Repairs of the cables will depend on the number and location of cable breaks and the availability of repair ships. Although the economic impact of impaired communication after a PNW earthquake is unknown, it is thought that it will result in time delays in rerouting the supply chain for all sectors of Alaska's economy, resulting in increased costs.

\section{Conclusions and Recommendations}

A full analysis of the economic impacts across the entire spectrum of Alaska's economy is beyond the scope of this paper. The aftereffects of a PNW earthquake on the transportation, freight, oil, tourism, fishing and communication sectors of the economy described above are thought to have the largest and most direct impacts on Alaska and its citizens. Other sectors of the economy will likely suffer unknown setbacks. For example, shortages in building materials may affect the construction sector and increased fuel costs could hinder civilian and military endeavors. It is clear that a more detailed evaluation of the potential impacts on Alaska from future PNW earthquakes is necessary.

Based on the relative seismic quiescence in the PNW over the last 100 years and the mounting evidence for multiple Holocene earthquakes, it would be in the best interest of the State of Alaska to initiate an economic study to evaluate the expected monetary losses associated with disrupted PNW supply chains. A better understanding of potential losses related to PNW earthquakes will help provide the state of Alaska a basis on which to develop alternative distribution plans and mitigation strategies to minimize their impacts on Alaska.

\section{References}

1 Wang, Yumei, and Clark, J.L., 1999, Earthquake damage in Oregon-Preliminary estimates of future earthquake losses: Oregon Department of Geology and Mineral Industries (DOGAMI), Special Paper 29, 59 p.

2 CREW (Cascadia Region Earthquake Workgroup), 2005, Cascadia Subduction Zone earthquake: A magnitude 9.0 earthquake scenario: Oregon Department of Geology and Mineral Industries Open File Report O-05-05, 24 p.

3 CREW (Cascadia Region Earthquake Workgroup), 2009, Cascadia shallow earthquakes: Cascadia Region Earthquake Workgroup, 32 p., http://www.crew.org/sites/default/files/CREWshallowFinalSmall.pdf.

4 Homeland Security, 2012, Draft Analytical Baseline Study for the Cascadia Earthquake and Tsunami, National Infrastructure Simulation and Analysis Center, Homeland Infrastructure Threat and Risk Analysis Center, Office of Infrastructure Protection, National Protection and Programs Directorate. 
5 Atwater, B.F., 1987, Evidence for great Holocene earthquakes along the outer coast of Washington State: Science, v. 236, no. 4804, p. 942-944.

6 Atwater, B.F., Nelson, A.R., Clague, J.J., Carver, G.A., Yamaguchi, D.K., Bobrowsky, P.T., Bourgeois, Joanne, Darienzo, M.E., Grant, W.C., Hemphill-Haley, Eileen, Kelsey, H.M., Jacoby, G.C., Nishenko, S.P., Palmer, S.P., Peterson, C.D., and Reinhart, M.A., 1995, Summary of coastal geologic evidence for past great earthquakes at the Cascadia subduction zone: Earthquake Spectra, v. 11, no. 1, p. 1-18.

7 Atwater, B.F., and Hemphill-Haley, Eileen, 1997, Recurrence intervals for great earthquakes of the past 3,500 years at northeastern Willapa Bay, Washington: U.S. Geological Survey Professional Paper $1576,108 \mathrm{p}$.

8 Nelson, A.R., Atwater, B.F., Bobrowsky, P.T., Bradley, Lee-Ann, Clague, J.J., Carver, G.A., Darienzo, M.E., Grant, W.C., Krueger, H.W., Sparks, R.J., Stafford, T.W., and Stuiver, Minze, 1995, Radiocarbon evidence for extensive plate-boundary rupture about 300 years ago at the Cascadia subduction zone: Nature, v. 378, no. 6555, p. 371-374.

9 Satake, Kenji, Shimazaki, Kunihiko, Tsuji, Yoshinobu, and Ueda, Kazue, 1996, Time and size of a giant earthquake in Cascadia inferred from Japanese tsunami records of January 1700: Nature, v. 379, no. 6562 , p. 246-249.

${ }^{10}$ Haugerud, R.A., Harding, D.J., Johnson, S.Y., Harless, J.L., Weaver, C.S., and Sherrod, B.L., 2003, High-resolution lidar topography of the Puget Lowland, Washington-A bonanza for earth science: GSA Today, v. 13, no. 6, p. 4-10.

${ }^{11}$ Nelson, A.R., Johnson S.Y., Kelsey, H.M., Wells, R.E., Sherrod, B.L., Pezzopane, S.K., Bradley, LeeAnn, Koehler, R.D., and Bucknam, R.C., 2003, Late Holocene earthquakes on the Toe Jam Hill fault, Seattle fault zone, Bainbridge Island, Washington: Geological Society of America Bulletin, v. 115, no. 11, p. 1,388-1,403.

12 Ayers, W.E., Campbell, Casey, Grewe, Nicole, and Kelsey, Mark, eds., 2009, Alaska Economic Performance Report, State of Alaska 2009: State of Alaska, Department of Commerce, Community \& Economic Development, 44 p., http://www.commerce.state.ak.us/ded/pub/2009_Performance_Report_web.pdf.

${ }^{13}$ Goldsmith, S.A., and Killorin, Mary, 2011, Annual Report for the Construction Industry Progress Fund and the Associated General Contractors of Alaska: Anchorage, University of Alaska Anchorage Institute of Social and Economic Research, 8 p., http://www.iser.uaa.alaska.edu/Publications/2012-ConstructionForecast.pdf.

${ }^{14}$ Washington Public Ports Association, 2006, Trade statistics website, http://www.washingtonports.org/issues_areas/economic_development/trade_statistics.asp (viewed 7/24/2012)

${ }^{15}$ Port of Tacoma, 2007, “Totem Ocean Trailer Express and Port Agree to Restated Lease for Redeveloped Terminal” (September 28, 2007), news release on company website, http://www.portoftacoma.com/Page.aspx?cid=1420 (viewed 7/24/2012).

${ }^{16}$ Alaska Department of Revenue, Tax Division, 2010, Revenue Sources Book, Fall 2010, posted on website, http://www.tax.alaska.gov/programs/documentviewer/viewer.aspx?2136f (viewed 7/24/2012).

${ }^{17}$ Tanker traffic data, 2010, State of Alaska, Department of Revenue, Tax division

${ }^{18}$ Hostler, Kevin, 2006, Terminal storage capacity is sized for pipeline flow: Prince William Sound Regional Citizens' Advisory Council, Alyeska Pipeline Service Company Viewpoint, http://www.pwsrcac.org/newsroom/obs0605/terminal.html

${ }^{19}$ Center for Land Use Interpretation, Washington State, http://ludb.clui.org/tag/state:WA/

${ }^{20}$ McDowell Group, 2010, Economic Impact of Alaska's Visitor Industry: Juneau, State of Alaska Department of Commerce, Community \& Economic Development, 37 p., http://commerce.alaska.gov/ded/dev/pub/Visitor Industry Impacts 3 30.pdf.

${ }^{21}$ Keith, Brynn, and Whitney, Sara, 2011, Alaska Economic Trends: Alaska Department of Labor \& Workforce Development, Alaska Economic Trends, v. 31, no. 6, June 2011, 19 p., http://www.labor.state.ak.us/trends/jun11.pdf.

${ }^{22}$ Northern Economics, Inc., 2009, The seafood industry in Alaska's economy: Anchorage, prepared for Marine Conservation Alliance, At-Sea Processors Association, Pacific Seafood Processors Association, 93 p., http://www.marineconservationalliance.org/wp-content/uploads/2010/06/SIAE_Jan09-1.pdf. 